University of Michigan Law School

University of Michigan Law School Scholarship Repository

Law \& Economics Working Papers

$1-31-2012$

\title{
U.S. Treaty Anti-Avoidance Rules: An Overview and Assessment
}

Reuven S. Avi-Yonah

University of Michigan Law School, aviyonah@umich.edu

Oz Halabi

University of Michigan Law School, ozh@umich.edu

Follow this and additional works at: https://repository.law.umich.edu/law_econ_current

Part of the Tax Law Commons

\section{Working Paper Citation}

Avi-Yonah, Reuven S. and Halabi, Oz, "U.S. Treaty Anti-Avoidance Rules: An Overview and Assessment" (2012). Law \& Economics Working Papers. 45.

https://repository.law.umich.edu/law_econ_current/art45

This Article is brought to you for free and open access by University of Michigan Law School Scholarship Repository. It has been accepted for inclusion in Law \& Economics Working Papers by an authorized administrator of University of Michigan Law School Scholarship Repository. For more information, please contact mlaw.repository@umich.edu. 
BIT 4-5/2012 - BOSTON IFA CONGRESS SPECIAL ISSUE

United States

US Treaty Anti-Avoidance Rules: An Overview and Assessment

Reuven S. Avi-Yonah* and Oz Halabi**

*Irwin I. Cohn Professor of Law, the University of Michigan. The author can be contacted at aviyonah@umich.edu.

**SJD Candidate, the University of Michigan. The author can be contacted at ozh@umich.edu.

In this article, the authors provide a summary of the antiavoidance rules in the United States that relate to bilateral tax treaties. Specifically, they focus on treaty-based antiavoidance rules and discuss whether or not a General AntiAvoidance Rule would be appropriate in this context. ok

1. Introduction

Anti-avoidance rules are a tool used to eliminate the abusive behaviour of taxpayers seeking to reduce their tax burden on business and investment transactions. A taxpayer should, can and even must structure a transaction or a business to be associated 
with as few tax consequences as possible. However, when the only or the primary reason for choosing the structure is tax motivated it should be considered to be abusive behaviour and ought to be countered by the legislator. One way to counter such abusive behaviour is by enacting anti-avoidance rules.

There are several ways to put in place anti-avoidance rules and there are several types of those rules. In general, antiavoidance rules may be divided into two main groups: (1) General Anti-Avoidance Rules (GAARs); and (2) Specific Anti-Avoidance Rules (SAARs). There are also several ways to enact and implement anti-avoidance rules, i.e. by domestic legislation, bilateral and multilateral agreements, court decisions, for example, the European Court of Justice in the European Union, or by the enforcement, interpretation and policy of domestic authorities.

While SAARs are promulgated to counter a specific abusive behaviour, GAARs are used to support SAARs and to cover transactions that are not covered by SAARs. Accordingly, abusive behaviour on the part of a taxpayer that might defeat a SAAR either due to technicalities or sophisticated planning might eventually be targeted and disallowed or recharacterized by a GAAR. However, an essential prerequisite of characterizing 
taxpayer actions is a description of the specific actions to be so categorized. ${ }^{1}$ Consequently, one question, which may be asked, is whether SAARs are necessary and whether a GAAR might be sufficient to counter abusive transactions.

In this article, the authors provide a broad summary of the anti-avoidance rules used in the United States that relate to its bilateral tax treaties. The primary anti-avoidance rules used by the United States in its domestic legislation are the thin capitalization rules (earnings stripping), expatriation tax, transfer pricing, substance-over-form, step transaction, economic substance, limitation on hybrid entities, anti-conduit regulations, and the Foreign Account Tax Compliance Act (FATCA) rules. ${ }^{2}$ The anti-avoidance rules included in most of us tax treaties are beneficial ownership, limitation on benefits (LOB) and limitation on residents. In this article, the authors also focus on treaty-based anti-avoidance rules. They then discuss whether or not a GAAR would be appropriate in the context of US tax treaties.

2. Limitation on Hybrid Entities ${ }^{3}$

\footnotetext{
1. J.D. Rosenberg Tax Avoidance And Income Measurement, 87 Mich. L. Rev. p. 365 (Nov. 1988).

2. At the time of the writing of this article, the FATCA rules were not yet in force.

3. According to the Joint Committee on Taxation Report [JCS-23-97], at p. 251, it was estimated that the provision would increase federal fiscal year budget receipts by USD 1 million per year in each of the years 1998 to
} 
In 1997, the US Treasury promulgated regulations under the section 7701 classification rules of the US Internal Revenue Code (IRC), ${ }^{4}$ known as the "check-the-box" regulations. Pursuant to the regulations, entities, whether domestic or foreign, can be considered for tax purposes to be partnerships and, therefore, their income is subject to tax at the hands of their members or beneficiaries. However, this rule applies only to entities that are not considered to be "per se corporations". Per se corporations are considered to be corporations for tax purposes and, therefore, taxed as separate entities, notwithstanding the check-the-box regulations. ${ }^{5}$ Consequently, any other entity that is not considered to be per se and wishes to be taxed as corporation should make an election either by the entity or its members to be allowed such a tax treatment. The election is available to any entity, in addition to per se corporations, even if taxed differently in the home country, i.e. taxed as a partnership in the United States and as a separate entity in the other jurisdiction and vice versa. As a result of the potential of different tax treatment in two jurisdictions, avoiding taxes in multiple tax jurisdictions became easily accessible. The US Congress, therefore, became

2007. It is beyond the scoop of this article to argue whether this estimate was correct and especially, if correct, whether it was justify to introduce section 894 and its regulations.

4. $\quad$ IRC Regs. 301.7701-2 to 301.7701-3.

5. The list of per se corporations is contained in IRC Regs. 301.7701-2(b). 
concerned as to the potential tax-avoidance opportunities available for foreign investors in the United States through dual tax classification entities (hybrid entities) ${ }^{6}$

\section{[PCD single spaced]}

In particular, the Congress understood that the interaction of the tax laws and the applicable tax treaty could provide a business structuring opportunity that would allow Canadian corporations with U.S. subsidiaries to avoid both U.S. and Canadian income taxes with respect to those U.S. operations .

Pursuant to these concerns, ${ }^{7}$ in 1997 , the Congress enacted section 894(c) to deny the limited withholding tax rates, provided by tax treaties with regard to any item of income that is subject to tax in the United States. The denial of the benefits is imposed when the income is derived through an entity that, under US tax law, is treated as a hybrid entity, provided that the income is not considered: (1) to be derived and taxed by the foreign person under the tax laws of the treaty state; (2) the tax treaty does not contain a provision on its application in respect of an item of income derived through a

6. Joint Committee on Taxation Report [JCS-23-97], at p. 249. See also HR Rep. No. 148, 105th Cong., 1st Sess. 550 (1997. For the structure described by the Committee, see [Initials] Klein \& [Initials] Renfroe, Section 894: Payments to Flow-Through Entities, 26 Tax Mgt. Intl. J. P. 547 (1997).

7. $\quad$ HR Rep. No. 148, 105th Cong., 1st Sess. 550 (1997). 
Law \& Economics W orking Papers, Art. 45 [2012]

partnership; ${ }^{8}$ and (3) the treaty state does not impose tax on a distribution of such income from such an entity to such a person. ${ }^{9}$

In 2002, the US Internal Revenue Service (IRS) and the US Treasury finalized and introduced Reg. 1.894-1(d), which is a special rule for items of income received by entities in attempt to provide additional taxpayer certainty in complex settings regarding the consequences of partnership or corporate status and the availability of treaty benefits. The regulations apply in respect of all income tax treaties to which the United States is a party with the exception of when the United States and the other treaty partner "otherwise explicitly agreed upon" either in the treaty text or by a mutual agreement procedure (MAP) taken by the competent authorities of the two countries. ${ }^{10} \mathrm{An}$ entity is eligible to the reduced withholding tax rate in a relevant tax treaty only to the extent that the income is derived by a resident ${ }^{11}$ of the treaty partner jurisdiction, and taxed accordingly. ${ }^{12}$

\footnotetext{
8. See US Model Income Tax Convention art. 1(6) (15 Nov. 2006), Models IBFD regarding transparent entities.

9. $\quad$ See HR Rep. No. 148, 105th Cong., 1st Sess. 550 (1997) (a foreign country is "considered to impose tax on a distribution even though such tax may be reduced or eliminated by ... deductions or credits otherwise available to the taxpayer"). See also B.B. Bittker \& L. L.Lokken: Federal Taxation of Income, Estates, and Gifts para. 67.3. Treaty Limitations and Antiabuse Rules (WG\&L 2009z009).

10. Reg. Sec. 1.894-1(d)(4).

11. Under Reg. Sec. 1.894-1(d)(3)(v) a person is a determined as resident of a treaty jurisdiction according to the rules of the tax treaty.

12. Reg. Sec. 1.894-1(d)(1).
} 


\section{Beneficial Ownership}

The beneficial owner requirement is a SAAR found in most US tax treaties and also in the OECD Model (2010) $)^{13}$ and the UN Model (2001). ${ }^{14}$ In general, the beneficial ownership requirement is situated in articles 10, 11 and 12 of tax treaties, dealing with dividends, interest and income from royalties, respectively. ${ }^{15}$ Some countries also add the beneficial ownership requirement to article 13 dealing with capital gains. ${ }^{16}$

Article 10(1) provides that income from dividends may be taxed in the state where the recipient is a resident. Articles 11(1) and 12(1) provide that an income from interest and royalties may be taxed only in the state where the recipient is a resident. However, article 10(2) allows the state of source to impose withholding tax on such income in accordance to the source state's domestic laws. In addition, the article limits the source state to imposing withholding tax at a rate that is usually lower or equal to that provided for by domestic law ( $\odot \%$ to $15 \%)$. The residence state's sole taxing right and the reduced

13. OECD Model Tax Convention on Income and on Capital (22 July 2010), Models IBFD.

14. UN Model Tax Convention on Income and on Capital (1 Jan. 2001), Models IBFD.

15. Reference to articles in this section are to the articles of the US Model (2006).

16. See, for example, Agreement Between the Government of the State of Israel and the Government of the Republic of Singapore for the Avoidance of Double Taxation and the Prevention of Fiscal Evasion with respect to Taxes on Income art. 13(5) (19 May 2005), Treaties IBFD. 
tax rate granted to the source state only applies when the beneficial owner of the income is a resident of the other contracting state. ${ }^{17}$ otherwise, the source state may impose tax in accordance to its domestic law. In the United States, according to sections 1441-1443 of the IRC, income from dividends, interest and royalties (FDAP) sourced in the United States is subject to a $30 \%$ withholding tax.

The reduced (or no) tax rate imposed by the source state applies only when the beneficial owner is a resident of the other contracting state. Accordingly, in situations where the recipient is not the beneficial owner, the treaty rate is allowed if it can be demonstrated that the beneficial owner is a resident of the treaty state, even if not the recipient. For instance, if a US-based company pays dividend to a resident of the United Kingdom, to withhold taxes under the United KingdomUnited States Income Tax Treaty (2001), ${ }^{18}$ the beneficial owner must be UK resident.

17. It should be noted that, in OECD Model Tax Convention on Income and on Capital (1995), the OECD amended OECD Model Tax Convention on Income and on Capital (11 Apr. 1977), Models IBFD by replacing the words "if the recipient is the beneficial owner of the dividends" with "if the beneficial owner of the dividends is a resident of the other Contracting State". However, in the US Model Income Tax Convention (20 Sept. 1996), Models IBFD and US Model (2006) the wording is " ... if the dividends are beneficially owned by a resident of the other Contracting State". Accordingly, the demand that the income is received by the beneficial owner, as was the case in the OECD Model before 1995, was not included in the US Model and was subsequently also omitted from the OECD Model.

18. Convention Between the Government of the United Kingdom of Great Britain and Northern Ireland and the Government of the United States of America for the Avoidance of Double Taxation and the Prevention of Fiscal Evasion with respect to Taxes on Income and on Capital Gains (24 July 2001), Treaties IBFD [hereinafter: U.K.U.S. Income Tax Treaty]. 
The term "beneficial owner" is defined neither in tax treaties nor in the various models. This fact, together with the different interpretations given to the term by different countries and courts, increases uncertainty and costly litigation between tax authorities and taxpayers. ${ }^{19}$ In addition, even more complications are associated with the fact that the concept of beneficial ownership or beneficial owner is not recognized in the civil law countries that are members of the OECD, ${ }^{20}$ which raise the possibility that disagreement might arise between countries that might be unappeasable, even through a MAP. In one decision, ${ }^{21}$ a court in Canada held that a holding company is considered to be the beneficial owner with regard to Canada-Netherlands Income Tax Treaty (1986). ${ }^{22}$ That decision was given by the court, despite the fact that the holding company had minor activities and assets, and received and distributed dividends almost simultaneously. The court had a long debate as to how to define the term "beneficial" owner when the source state was a civil law country and the recipient state was in a common law country.

19. For a broader explanation and concern as to multilateral disagreement, see P. Baker, Beneficial Ownership: After Indofood, 6 GITC Rev. 1 (Feb. 2007).

20. CA: TC, 22 Apr. 2008, Prévost Car Inc. v. Her Majesty the Queen, 2004-2006(IT)G and 2004-4226(IT)G, Tax Treaty Case Law IBFD.

21. Id.

22. Convention Between the Kingdom of the Netherlands and Canada for the Avoidance of Double Taxation and the Prevention of Fiscal Evasion with respect to Taxes on Income (27 May 1986) (as amended through 1997), Treaties IBFD. 


\section{Limitation on Benefits}

States regard a tax treaty as a vehicle to provide treaty benefits to residents of the contracting states, the parties to the agreement, as achieved by their treaty delegation. The question that is, therefore, raised in respect of this approach is who is entitled to be treated as a resident of a contracting state and so to enjoy treaty benefits.

Although the text of the OECD Model does not have express antiabuse provisions, the Commentary on Article 1 of the OECD Model $(2010)^{23}$ contains an extensive discussion approving the use of such provisions in tax treaties to limit the ability of third country residents to obtain treaty benefits.

The United States' position is that tax treaties should include specific, broad and detailed provisions to prevent misuse of tax treaties by residents of third countries. Consequently, the US Model (1981), ${ }^{24}$ as amended in 1996 and again in 2006, includes LOB provisions and, therefore, most US tax treaties contain comprehensive LOB provisions that include some changes comparing

23. OECD Model Tax Convention on Income and on Capital: Commentary on Article 1 (22 July 2010), Models IBFD.

24. US Model Income Tax Convention (16 June 1996), Models IBFD. 
to the US Model (2006). ${ }^{25}$ In general, a tax treaty that provides benefits to a resident of a contracting state permits the use of the tax treaty by residents of third countries to obtain the benefits of a tax treaty between the two contracting states by way of a legal entity formed in one of the two contracting state, i.e. treaty shopping.

It should be noted that not every case of a third country resident establishing legal entity in other state is considered to be treaty shopping. If there are substantial reasons for establishing the structure that were unrelated to obtaining treaty benefits, the structure does not fall within the definition of "treaty shopping".

Article 22 and the anti-abuse provisions of domestic law complement each other, as article 22 effectively determines whether an entity has a sufficient nexus to the contracting state to be treated as a resident for treaty purposes, while the domestic anti-abuse provisions, for example, the business purpose, substance-over-form, step transaction or conduit principles, determine whether a particular transaction should be recast in accordance with its substance. Accordingly, the

25. The US tax treaties with Greece, Hungary, Pakistan, Philippines, Poland and Romania do not contain LOB provisions. 
internal law principles of the source state may be applied to identify the beneficial owner of an item of income and article 22 is then applied to the beneficial owner to determine if that person is entitled to the benefits of the tax treaty with regard to the income. ${ }^{26}$

The LOB article of the US Model (2006) reflects significant changes to the LOB article of the US Model (1996). These changes are intended to make it more difficult for third country residents to benefit inappropriately from a tax treaty. When a resident of one state derives income from another, the domestic tax laws of the two countries may cause that income to be taxed in both countries, either because of source: resident taxation or because of source:source taxation. Consequently, one purpose of a tax treaty is to prevent the double taxation of residents of the treaty states by allocating taxing rights in respect of cross-border transactions. As noted previously, although a tax treaty is intended to apply only to residents of the two treaty states, residents of a third country may attempt to benefit from a tax treaty by engaging in tax favourable structuring.

From the early 1980s, the United States, when signing tax treaties, has insisted on including an LOB denying treaty

26. US Model Income Tax Convention Technical Explanation (15 Nov. 2006), Models IBFD. 
benefits if a person to whom treaty benefits should be granted is not the taxpayer resident in one of the states.

The US Model (1980) contained an LOB provision, in article 16, that denied treaty benefits to an entity that was resident in one of the contracting states unless more than $75 \%$ of the beneficial interest in the entity were owned by individuals resident of the same state and no substantial part of its income was paid out from the entity as interest, royalties or other deductible payments to residents of a third country. That double test encompassed the ownership and the base erosion tests to the effect that an entity established in a foreign state was owned by residents of that state so as to eliminate the use of such an entity. This was because, in paying all its income to a third country, the base erosion test requires that a substantial part of its profits remain in that country. Article 16 also denied treaty benefits if the income was subject, in the residence state, to lower tax than that which would apply to similar income arising in that state that was derived by resident of the other state.

These strict rules were an obstacle to bona-fide structures forming a real business due to the ownership test, as they demanded a high ownership threshold. Beginning with the protocol 
Law \& Economics W orking Papers, Art. 45 [2012]

to the Italy-United States Income Tax Treaty (1984), ${ }^{27}$ a $50 \%$

ownership threshold was introduced as opposed to the previous

75\% threshold in respect of the ownership and base erosion

tests. ${ }^{28}$ The new threshold was included in tax treaties

negotiated and signed in the 1990s. ${ }^{29}$

The US Model (1996) substantially refined the LOB article and

tax treaties signed few years latter reflected the provisions

contained in that Model. The US Model (2006) changed the LOB

article yet again. This has found expression in the recent tax

treaty negotiated and signed by the United States.

The LOB articles included in recent tax treaties and protocols are generally similar to each other as well as to the us Model (2006). Nonetheless, there are some differences. Specifically, the public trading test, the derivative benefits rules $^{30}$ and the foreclosure eligibility in respect of treaties benefit certain triangular arrangements. ${ }^{31}$ The US Model (2006) does not, however,

27. Convention Between the Government of the United States of America and the Government of the Italian Republic for the Avoidance of Double Taxation with respect to Taxes on Income and the Prevention of Fraud or Fiscal Evasion (17 Apr. 1984), Treaties IBFD.

28. For instance, Convention Between the Government of the United States of America and the Government of the Republic of Indonesia for the Avoidance of Double Taxation and the Prevention of Fiscal Evasion with respect to Taxes on Income art. 28(6)-(8) (1 July 1988), Treaties IBFD.

29. $\quad$ Bittker \& Lokken, supra n. 9.

30. This is intended to grant treaty benefits to a treaty state resident if the resident's owners would have been entitled to the same benefits had the income flowed directly to them.

31. An arrangement whereby income, such as interest, is lightly taxed because it is derived by a third country $\mathrm{PE}$ of a treaty state resident. 
include special derivative benefits rules or rules for triangular arrangements.

Article 22 of the US Model (2006) contains a list of persons who are entitled to the benefits of the tax treaty and refers to them as "qualified persons". Persons who do not fall within the definition of a qualified person may, nevertheless, be entitled to the benefits of a tax treaty under certain conditions as is explained below.

Article 22(1) of the US Model (2006) grants treaty benefits to individual resident of a treaty state. However, if the individual is used as a device to obtain treaty benefits for a resident of a third country and is, therefore, not considered to be the beneficial owner in respect of the income, the benefits are denied. ${ }^{32}$ Under article $22(1)$ and (3), an entity resident in a treaty state is entitled to treaty benefits only if it falls within one of the following categories.

The article treats some persons as qualified persons and, therefore, as entitled to treaty benefits with no restrictions, but other persons are only treated as such subject to limitations. The US Model (2006) allows treaty benefits to

32. US Model (2006), Technical Explanation regarding the term "beneficial ownership". 
governments, political subdivisions and local authorities of a contracting state. This provision is narrower than the corresponding provision of the US Model (1996), which allowed treaty benefits to any qualified governmental entity, including entities owned by the treaty state, governmental pension funds and the governing body of the contracting state. ${ }^{33}$

5. Recent Developments ${ }^{34}$

\subsection{Introductory remarks}

The tax treaties and protocols signed by the United States in recent years have changed compared to the US Model (2006) following the introduction of a new article that reflects the anti-treaty-shopping provisions.

The traditional LOB provision in the US Model (2006) applies only if the principal class of a company's shares is primarily traded on a recognized stock exchange located in the company's residence state. However, for example, the public trading tests

33. See art. 22(2)(b) US Model (1996).

34. Joint Committee on Taxation, Testimony of the Staff of the Joint Committee on Taxation Before the Senate Committee on Foreign Relations Hearing on the Proposed Tax Protocols with Sweden and France and the Proposed Tax Treaty with Bangladesh (JCX- 08-06) (2 Feb. 2006). 
in the Belgium-United States Income (2006), ${ }^{35}$ Denmark-United

States Income (1999) ${ }^{36}$ and Finland-United States Income and

Capital $(1898)^{37}$ Tax Treaties may be satisfied by trading on a stock exchange located in a company's residence state in other jurisdictions that are considered to be part of the economic area that includes the relevant treaty state. Such tax treaties include the derivative benefits rules that are intended to grant treaty benefits to a treaty state resident if the resident's owners would have been entitled to the same benefits had the income flowed directly to them.

\subsection{Triangular arrangements}

Despite the absence of a triangular arrangements provision in the US Model (2006), the Belgium-United States Income (2006), Denmark-United States Income (1999) and Finland-United States Income and Capital (1898) Tax Treaties include rules that are intended to prevent eligibility for treaty benefits arising in respect of certain triangular arrangements. Such arrangements include where interest on a loan is lightly taxed, as it is

35. Convention Between the Government of the United States of America and the Government of the Kingdom of Belgium for the Avoidance of Double Taxation and the Prevention of Fiscal Evasion with respect to Taxes on Income (27 Nov. 2006), Treaties IBFD.

36. Convention Between the Government of the United States of America and the Government of the Kingdom of Denmark for the Avoidance of Double Taxation and the Prevention of Fiscal Evasion with respect to Taxes on Income (19 Aug. 1999) (as amended through 2006), Treaties IBFD.

37. Convention Between the Government of the United States of America and the Government of the Republic of Finland for the Avoidance of Double Taxation and the Prevention of Fiscal Evasion with respect to Taxes on Income and on Capital (21 Sept. 1989) (as amended through 2006), Treaties IBFD. 
derived by a third-country permanent establishment (PE) of a treaty state resident.

This provision is likely to appear on tax treaties with countries that use the exemption method to eliminate double taxation, rather than the credit method. Some countries, for example, Belgium, Denmark and Germany, have moved towards a territorial tax system, which, in general, taxes income generated within the country. In such countries, the income of a resident company derived through a PE located in a treaty state is exempt from tax in the residence state.

The Belgium-United States Income Tax Treaty (2006) includes rules that are intended to allow treaty benefits for certain treaty state residents functioning as headquarters companies. Although the US Model (2006) does not include special limitation-on-benefits rules for headquarters companies, similar rules have been included in the Australia-United States (1982) ${ }^{38}$ and the Netherlands-United States (1992) ${ }^{39}$ Income Tax Treaties. The 2006 protocol to the Denmark-United States Income Tax Treaty (1999) includes rules that are intended to allow treaty benefits

38. Convention Between the Government of the United States of America and the Government of Australia for the Avoidance of Double Taxation and the Prevention of Fiscal Evasion with respect to Taxes on Income (6 Aug. 1982), Treaties IBFD

39. Convention Between the Kingdom of the Netherlands and the United States of America for the Avoidance of Double Taxation and the Prevention of Fiscal Evasion with respect to Taxes on Income (18 Dec. 1992), Treaties IBFD. 
to certain Danish taxable non-stock corporations and Danish companies owned by taxable non-stock corporations. Taxable nonstock corporations are entities designed to preserve control of certain Danish operating companies through control of the companies' voting stock. The 2006 protocol to the Germany-United States Income and Capital Tax Treaty $(1989)^{40}$ includes special rules for determining whether or not certain German investment vehicles are entitled to treaty benefits. Under article 1(1) of the US Model (2006), as well as article 1 of the OECD Model (2010), a foreign person is entitled to treaty benefits in respect of the relevant tax treaty only if the person is a resident of the foreign state with which the United States has concluded the tax treaty.

The 2005 protocol to the Sweden-United States Income Tax Treaty $(1994)^{41}$ applies to triangular branch structures in respect of certain types of US income earned. Under the rule, some payments of interest, royalties and insurance premiums paid by a us payor to a PE of a Swedish resident in a third country may be subject to US withholding tax if Sweden does not tax the income and the third country only taxes it lightly. However, the 2005 protocol

40. Convention Between the Federal Republic of Germany and the United States of America for the Avoidance of Double Taxation and the Prevention of Fiscal Evasion with respect to Taxes on Income and Capital and to Certain Other Taxes (29 Aug. 1989) (as amended through 2006), Treaties IBFD.

41. Convention Between the Government of Sweden and the Government of the United States of America for the Avoidance of Double Taxation and the Prevention of Fiscal Evasion with respect to Taxes on Income (1. Sept. 1994) (as amended through 2005), Treaties IBFD. 
limits the US withholding tax to $15 \%$ in respect of interest and royalties, rather than applying the $30 \%$ withholding under US domestic law.

\subsection{Recognized stock exchanges}

Most $\angle O B$ articles provide that a company that is a resident of a treaty state qualifies for treaty benefits, without regard to whether or not any other tests are satisfied, if there is substantial and regular trading of its principal class of stock on an approved stock exchange located in one of the two treaty states. Recognized stock exchanges typically include the NASDAQ and/or any US exchange established under the Securities Exchange Act (1934), one or more exchanges in the other contracting state, and other exchanges as may be agreed by the competent authorities.

Under the France-United States Income and Capital Tax Treaty (1994), ${ }^{42}$ recognized stock exchanges include the following: (1) the NASDAQ and any stock exchange registered with the US Securities and Exchange Commission (SEC) as a national securities exchange for purposes of the Securities Exchange Act

42. Convention Between the Government of the United States of America and the Government of the French Republic for the Avoidance of Double Taxation and the Prevention of Fiscal Evasion with respect to Taxes on Income and Capital (31 Aug. 1994), Treaties IBFD. 
(1934); (2) the French stock exchanges controlled by the Commission des operations de bourse; and (3) the exchanges of Amsterdam, Brussels, Frankfurt, Hamburg, London, Madrid, Milan, Sydney, Tokyo and Toronto, and any other stock exchanges as may be agree by the competent authorities.

Under the Netherlands-United States Income Tax Treaty (1992), recognized stock exchanges include any stock exchange registered with the SEC, the NASDAQ, the Amsterdam Stock Exchange or the parallel market of the Amsterdam Stock Exchange, except with regard to closely held companies, and any other exchange as may be agreed by the competent authorities. The competent authorities have expanded this list to include the exchanges in Brussels, Frankfurt, Hamburg, London, Madrid, Milan, Paris, Sydney, Tokyo and Toronto. The Hungary-United States (2010), ${ }^{43}$ Iceland-United States $(2007)^{44}$ and United Kingdom-United States (2001) Income Tax Treaties have expanded the stock exchanges covered by the definition of recognized stock exchanges to include not only the stock exchanges in the treaty partner's country, but also a list of other stock exchanges, usually from an EU Member States, but also from other countries with

43. Convention Between the Government of the United States of America and the Government of the Republic of Hungary for the Avoidance of Double Taxation and the Prevention of Fiscal Evasion with respect to Taxes on Income (4 Feb. 2010), Treaties IBFD.

44. Convention Between the Government of the United States of America and the Government of Iceland for the Avoidance of Double Taxation and the Prevention of Fiscal Evasion with respect to Taxes on Income (23 Oct. 2007), Treaties IBFD [hereinafter: Ice.-U.S. Income Tax Treaty]. 
attractive and active stock markets, such as Johannesburg, ${ }^{45}$ Sydney, Tokyo and Toronto. ${ }^{46}$

The publicly traded company test in the 2005 protocol to the Sweden-United States Income Tax Treaty (1994) includes general requirements, referred to as the "substantial presence" test, and defines a recognized stock exchange in respect of a company resident in the United States as a recognized stock exchange located in a third country that is a party to the North American Free Trade Agreement (NAFTA) or, in respect of a company resident in Sweden, as a recognized stock exchange located in the European Economic Area (EEA), the European Union or Switzerland.

5.4. Derivative benefits

Prior to the Netherlands-United States Income Tax Treaty (1992), the Jamaica-United States Income Tax Treaty (1980) ${ }^{47}$ was the only occasion on which the United States had agreed to a "derivative

45. U.K.-U.S. Income Tax Treaty.

46. Ice.-U.S. Income Tax Treaty and U.K.-U.S. Income Tax Treaty.

47. Convention Between the Government of the United States of America and the Government of Jamaica for the Avoidance of Double Taxation and the Prevention of Fiscal Evasion with respect to Taxes on Income (21 May 1980), Treaties IBFD. 
benefits" ${ }^{48}$ provision. In addition, only this tax treaty and the 1995 protocol to the Canada-United States Income Tax Treaty $(1980)^{49}$ apply the derivative benefits concept fully, without restriction to a particular group of countries. ${ }^{50}$

The absence of the derivative benefit resulted in a situation that a resident of a third state, which has a tax treaty with the United States that is in accordance to the US Model (2006), is not entitled to treaty benefits if investing or deriving income in the United States via an entity resident in another country that has a similar tax treaty with the United States, assuming that both states signed the same tax treaty with the United States that is consistent with the US Model. Such a disadvantage has no rationale. The reason for limiting the use of a tax treaty by way of an LOB provision is in respect of a resident of a non-treaty state investing in the United States through a treaty state. This is a rationale that can be accepted. Accordingly, the derivative benefits test was introduced to mitigate this abnormality in the LOB provision in the US Model. This change in the US perspective in relation to

48. A corporation resident in Jamaica and owned by a US corporation is entitled to treaty benefits, provided that it is held by an individual resident in third country and that individual would have been entitled to the benefits in an applicable tax treaty between the third country and the United States.

49. Convention Between Canada and the United States of America with respect to Taxes on Income and on Capital (26 Sept. 1980) (as amended through 1995), Treaties IBFD.

50. R.E. Anderson, Analysis of United States Income Tax Treaties current through 2011, (RIA Thompson 2011). 
the LOB provision is a matter of policy, as it has already been decided that the residents of third countries should qualify for this benefit and that, prima facie, the residents of the third countries are not treaty shopping by way of another [correct?] contracting state, as the same benefits are available in the home state.

The derivative benefit provisions in recent tax treaties, for example, in the United Kingdom-United States Income Tax Treaty (2001), provide that, if a resident company of one state that receives income from the United States is substantially owned by residents of a third country and that third country has a tax treaty with the United States that provides for the same benefits in respect of that income as in the tax treaty, there should be no objection to such third country residents obtaining that benefit indirectly via the tax treaty, as opposed to directly under the third country treaty with the United States.

5.5. Equivalent beneficiaries

An "equivalent beneficiary" is another extension of the US LOB article and can usually be found in the recent tax treaties signed by the United States with EU Member States. The definition of the term includes not only a resident of one of 
the contracting states, but also a resident of an EU or EEA Member State, but where there is a tax treaty between the EU or EEA Member State and the United States and would, under the tax treaty, be considered to be a "qualified person".

The need for an extension from a beneficiary to an equivalent beneficiary is in line with the Treaty on the Functioning of the European Union (2007), ${ }^{51}$ which prohibits discrimination in respect of establishment. In this regard, it should be noted that the rationale behind the concept of the freedom of establishment is, in general, to treat all the EU Member States as one.

\subsection{Limitation on residents}

Under most US tax treaties, and as provided for by the OECD and UN Models, the provisions of a tax treaty are limited to residents of one of the contracting states. One of the reasons for this explicit requirement is to avoid that misuse of a bilateral tax treaty by a person who is a not a resident of either of the contracting states. In this respect, article 4 of the OECD, UN and US Models provides that a resident of a

51. Treaty on the Functioning of the European Union (2007) OJ C 115 (2008), EU Law IBFD. 
contracting state is a person who under the laws of the home country is considered to be a resident.

Although the definition of a resident as provided by article 4(1) refers to the concept of residence as adopted in the domestic laws, the article indicates that the criteria to be considered in defining the term resident are those to the extent to which the term is based on the person's domicile, residence, place of management or any other criterion of a similar nature.

The fact that a person is determined to be a resident of a contracting state under the laws of that state does not necessarily entitle that person to the benefits of a tax treaty. In addition to being a resident under the domestic law, the term resident must also be in line with the criteria contained in article 4 of the tax treaty to be treated as resident for the application of the tax treaty and, therefore, to receive the benefits granted to the residents of a contracting state.

Accordingly, although the definition of a resident to whom a tax treaty might apply is borrowed from and relies on the domestic legislation of each of the contracting states, the various models ensure that the residence of a taxpayer is material and not technical, by providing for an exception to the rule in 
stating that the term "resident" does not include any person who is liable to tax in that contracting state only in respect of income from sources in that state or capital situated therein. ${ }^{52}$ Excluding persons who are subject to tax only on a territorial basis is intended to ensure that treaty benefits are only granted where the income derived abroad is taxed in the person's residence state. ${ }^{53}$

Tax treaties are not usually concerned with the domestic laws of the contracting states, or how the laws are structure or defined. ${ }^{54}$ This is, however, not true with regard to the definition of a resident. A tax treaty sets out the conditions under which a person is to be treated as fiscally resident and also includes a condition that that person is fully liable to tax in that state.

A tax treaty excludes from the definition of a resident a person who is not "liable to tax" in a contracting state under its laws. Consequently, tax treaties include an anti-avoidance rule to eliminate the potential double non-taxation when a person is

\footnotetext{
52. Art 4(1).

53. For a thorough explanation of the exclusion under art. 4(1), see OECD Model: Commentary on Article 4 (2010).

54. See art. 3(2) of the OECD, UN and US Models, which provides, without exception, that "any term not defined therein shall, unless the context otherwise requires, have the meaning that it has at that time under the law of that State for the purposes of the taxes to which the Convention applies, any meaning under the applicable tax laws of that State prevailing over a meaning given to the term under other laws of that State”.
} 
not liable to tax in the residence state and the source state does not tax the relevant income due to the application of a tax treaty, for example, article 11, which provides for a sole taxing right in respect of the residence state.

As the "liable to tax" condition has, in recent years, raised many questions regarding entities that are tax exempt in their residence state as to whether or not they are considered to be "liable to tax", countries have expressed their concerns and the OECD has responded. In this respect, the OECD has stated in paragraphs 8.6 to the Commentary on Article 4 (2010), that tax exempted entities, for example, pension funds:

[PCD single spaced]

may be exempted from tax, but they are exempt only if they meet all of the requirements for exemption specified in the tax laws. They are, thus, subject to the tax laws of a Contracting State. ${ }^{55}$ Furthermore, if they do not meet the standards specified, they are also required to pay tax.

\section{Conclusions: A GAAR for US Tax Treaties?}

55. See also the thorough discussion on the implications of "liability to tax" in OECD, The Granting of Treaty Benefits with respect to the Income of Collective Investment Vehicles (2010) [correct?], International Organizations' Documentation IBFD, inserted into paras. 6.9-6.34 of the OECD Model: Commentary of Article 1 (2010), especially paras. 6.11-6.16. 
As this article indicates, US tax treaties are subject to numerous SAARs. However, the question still remains as to whether or not a GAAR would be appropriate in this context.

The problem with US SAARs is that they tend to be very complicated and technical. A comparison of the LOB article in US tax treaties with that in the US Model (2006) suggests that actual LOBs have loopholes, introduced during the treaty negotiations, that can be exploited. Other SAARs, such as the anti-hybrid rule, are very narrow in scope.

The advantage of a GAAR is that is it by definition much broader and less subject to avoidance. The disadvantage is that a GAAR may deter legitimate transactions. However, the evidence from other countries that have GAARs suggests that with appropriate safeguards a GAAR is not a significant disincentive in respect of legitimate transactions, but, rather, that it restricts abusive tax planning. India and the United Kingdom are two countries that are currently contemplating adopting a GAAR for this reason.

The United States is unlikely to enact a GAAR any time soon. The enactment of the economic substance doctrine in 2010 may have an important effect on tax treaties. Before then, it was unclear as 
to whether or not the IRS had the authority to promulgate SAARs in a treaty context, such as conduit regulations, that could override tax treaties. Now, however, the IRS can argue that the conduit regulations are an application of economic substance, as conduits are likely to lack a bone fide business purpose. It may, therefore, be that, in the treaty context, the conduit regulations will now act essentially as a GAAR and apply to situations that are not caught by the SAARs described previously in this article. 